\title{
On the English Translation of Jian'ai by Late Qing Missionary-Sinologists
}

\author{
Chu Lijuan 褚麗娟 \\ Lecturer of School of History/Institute for Global History, \\ Beijing Foreign Studies University, Beijing, China \\ chulijuano505@163.com
}

\begin{abstract}
With an increasing volume of research being conducted on the transmission of premodern Chinese thought in the Western world, a plethora of studies have been published on the English translation of the ancient text Mozi, primarily through the lens of cross-cultural translation studies. Discussions on how the concept of jian'ai - often rendered as "universal love" - should be expressed in English have also taken place in this framework, while the topic has rarely been examined hermeneutically or with reference to histories of knowledge transfer, intellectuals, or scholarship. This article discusses the translation of jian'ai into English by the missionary-sinologists Joseph Edkins and James Legge during the mid-to-late 18oos. It points out that, while both scholars used the term "universal" to translate the concept, they differed on whether "equal" could be used. The author also demonstrates how differences in translation can signify differences in thinking. Using the "unit of thought" of hermeneutics as a methodology to study the translators' conception of jian'ai via a comparison of common structural levels, a case can be made that both of them used the criticism by Mengzi of Mozi as a kind of "situational construction". However, in terms of "situational processing", Edkin's demonstrated the necessity and equality of jian'ai by quoting the words of ancient sages and wise rulers just as Mozi did, while Legge focused on the "Teng Wen Gong I" chapter of the Mengzi, arguing that the idea of "equality" was not espoused by Mozi himself but rather his later followers. From the perspective of "situational fusion", Edkins pointed out that, while jian'ai is similar in form to the love of Christ, it in fact shares more similarities with utilitarianism. By contrast, Legge believed that jian'ai was more in line with the thought of Confucius, while he also discussed the similarities and differences between jian'ai and the love of Christ. The differing understandings of jian'ai arrived at by these two scholars demonstrates that missionaries sent to China
\end{abstract}


after the mid-nineteenth century underwent a transition from amateur to professional sinologists. Moreover, by examining how Mohism was introduced to the West in modern times, it can be shown how Legge's interpretation of jian'ai coined a longstanding translated name for the concept.

\section{Keywords}

missionary-sinologists - Joseph Edkins - James Legge - jian'ai - unit of thought

\section{Introduction $^{1}$}

As more scholars have begun to examine the transmission of Chinese classical thought to the West, the translation of premodern Chinese texts and terminology into non-Sinitic languages has become a popular avenue for research, especially over the past decade. It is in this context that the increasing number of translation studies on the ancient Chinese text the Mozi 墨子 have been conducted. In terms of content, these studies mainly examined the various English translations of the $\mathrm{Mozi}^{2}$ or the translation study of a single text, or the comparative study of several different translations. ${ }^{3}$ In addition, individual articles also discussed the translation of related terms. ${ }^{4}$ In terms of methodology, the translation studies of the Mozi usually make use of a particular translation theory, ${ }^{5}$ or

1 Supported by the "Fundamental Research Funds for the Central University" and "Beijing Social Science Foundation 北京市社科規劃一般項目 (project number 19wXB 005)”.

2 Due to space restrictions, the author is unable to provide an exhaustive overview of research in this area. A good starting point is Liao Zhiyang 廖志陽, “Mozi yingyi gaiguan《墨子》英譯 概觀 [A Brief English Translation History of the Mozi], Zhongnan daxue xuebao 中南大學 學報, no. 2 (2013): $232-36$.

3 For example Wang Hong 王宏, “Mozi yingyi duibi yanjiu《墨子》英譯對比研究 [A Study Comparing the Various English Translations of the Mozi]," Jiefangjun waiguoyu xueyuan xuebao 解放軍外國語學院學報, no. 6 (2006): 55-6o.

4 For example Zhang Yin 張茵, “Mozi Shangxian zhong fanyi duibi de tantao《墨子.尚 賢中》翻譯對比的探討 [Discussing a Comparison of Translations of the Second Part of the Shangxian Chapter in Mozi]," Kejiao wenhui (Zhongxun kan) 科教文匯 (中旬刊), Sep (2009): 251-65.

5 The translation of the Mozi into English has been examined from a variety of perspectives. For research through the lens of deep translation see Zhu Jianping 朱健平 et al., “Ai Qiao'en qi'e ban Mozi yingyi zhong shendu fanyi celüe yanjiu 艾乔恩企鵝版《墨子》英譯中深度 翻譯策略研究 [A Study of In-depth Translation Strategies in the English Translation of the Mozi by Ian Johnston Published by Penguin]," Waiyu jiaoxue 外語教學, no. 2 (2019): 99-103; or Deng Chun 鄧春, “Cong shendu fanyi de shijiao duibi fenxi Mozi liubu yingyiben:Yi 'jian'ai shang zhong xia' de yingyi wei li 從深度翻譯的視角對比分析《墨子》六部英譯本: 以“兼 
use hermeneutics as a methodology ${ }^{6}$ to scrutinize translation methods and the process of introduction to foreign readerships. Generally speaking, previous studies that discussed translation issues have tended to discuss the translation gains and losses of the Mozi and its individual terms from the standpoint of cross-cultural research with a focus on the actual differences between the Chinese and English languages. However, how to "situate" [qingjinghua 情境 化] the cross-cultural meaning presented in the English translations of the Mozi - especially from the history of concepts, knowledge transfer and hermeneutics - to reveal the significance of its scholarly and intellectual history has not been a common concern among scholars.

The earliest English translation of jian'ai 兼愛 that the author has sighted is that of Joseph Edkins [1823-1905], a missionary of the London Missionary Society, who published "Notices of the Character and Writings of Meh tsi" in 1859, wherein he translated the term as "equal and universal love". Later, when James Legge [1815-1897], also a missionary of the Society, published The Works of Mencius in 1861, he decided to translate sections I, II and III of the "Jian'ai" chapter into English. He used the phrase "universal love" to translate the term,

愛（上、中、下）'的英譯為例 [A Comparative Analysis of Six English Versions of the Mozi from the Perspective of Thick Translation, Taking the Translation of 'Jian'ai I, II, III' as an Example]," Waiyu jiaoyu yanjiu 外語教育研究, no. 2 (2015): 64-71; For discussions on translation standardization theory see Gao Yuanyuan 高媛媛, “Fanyi guifanlun shijiao xia Mozi yingyi duibi yanjiu 翻譯規範論視角下《墨子》英譯對比研究 [A Comparative Study of the English Translations of the Mozi from the Perspective of Translation Norm Theory]," Jiaoyu xiandaihua 教育現代化, no. 51 (2017): 294-5; For multimodal theory see Xu Bin 徐斌, Wang Jiali 王佳莉 and Yi Fang 易芳, “Duo motai shiyu xia Mozi yingyi tanxi 多模態視域 下《墨子》英譯探析 [An Analysis of the English Versions of the Mozi from the Perspective of Multimodality]," Chuangxin chuangye lilun yanjiu yu shijian 創新創業理論研究與實 踐, no. 17 (2020): 151-3. For discussions on the problem of variation in translation from a cross-cultural standpoint see Zou Su 鄒素, “Mozi zongjiao guannian yingyi bianyi yanjiu: Yi Li Shaokun yingyiben wei li《墨子》宗教觀念英譯變異研究: 以李紹芘英譯本為例 [A Study on Variations of Religious Concepts in English Translations of the Mozi: Taking Cyrus Lee's Version as an Example]," Heilongjiang shengtai gongcheng zhiye xueyuan xuebao 黑龍江生態工程職業學院學報, no. 2 (2017): 156-8. For discussions on text misinterpretation and translation strategies see Miao Xuemei 苗雪梅, “Mozi yingyiben zhong de wenben wushi yu fanyi celüe 《墨子》英譯本中的文本誤釋與翻譯策略 [Text Misinterpretations and Translation Strategies in English Versions of the Mozi]," Hebei guangbo dianshi daxue xuebao 河北廣播電視大學學報, no. 2 (2013): 6o-3. For discussions on translation comparison and retranslation issues see Liu Lisheng 劉立勝, “Mozi fuyi yu yizhe huayuquan jiangou celüe bijiao yanjiu《墨子》複譯與譯者話語權建構策略比較研究 [A Study on the Retranslations of the Mozi and Translators' Discourse Power Constructing Strategies]," Zhejiang waiguoyu xueyuan xuebao 浙江外國語學院學報, no. 1 (2017): 75-81.

6 Zhi Yu 支羽 and Zhu Bo 朱波, “Chanshixue shijiao xia de yizhe zhutixing: Cong Wang Rongpei de Mozi yingyi tanqi 䦴釋學視角下的譯者主體性: 從汪榕培的《墨子》英譯談 起 [Translator Subjectivity from the Perspective of Hermeneutics in Wang Rongpei's English Translation of the Mozi]," Xibei gongye daxue xuebao 西北工業大學學報, no. 4 (2013): 84-7. 
demonstrating his completely different view on whether jian'ai can connotate a sense of equality.

A concept is a collection of ideas - so when it is translated, a different translation is inevitably the result of a different way of thinking. The English translations of jian'ai by the two aforementioned missionary-sinologists reflect their theoretical "reconstruction" [chonggou 重構] of the term. This includes the process from textual understanding to theoretical reconstruction. How should scholars interpret the works of the missionary-sinologists? Lee Hsien-Chung 李賢中 from the Department of Philosophy at National Taiwan University has recently explored the use of the creative explanatory methodology of "unit of thought" [sixiang danwei 思想單位 $]^{7}$ as an ideological tool in the context of traditional Chinese literature. He posited that the unit of thought is a meaningful thinking situation that contains "so" [ ran 然], "why something is so" [suoyiran 所以然] and “reasoning factors" [silu yaosu 思路要素], and can deploy the theories of “situational construction" [qingjing gouzuo 情境構作], “situational processing” [qingjing chuli 情境處理] and “situational fusion” [qingjing ronghe 情境融合] proposed by hermeneutics. Lee makes the case that this is possible because the unit of thought touches upon the following aspects:

1. A description of the observed phenomenon, i.e., the situational structure of the unit of thought: What is there? What is it?

7 Lee Hsien-Chung 李賢中 posits that a “unit of thought” [sixiang danwei 思想單位] is a meaningful thinking situation. It is formed by converting objective things in a cognitive environment into subjective thinking situations or understanding objective words in the literature as one's own interpretation. A unit of thought contains "so" [ ran 然], "why something is so" [suoyiran 所以然] and “reasoning factors” [silu yaosu 思路要素]. It is derived from - but not equivalent to - the thinking situation. It is like a video in which some process fragments are "so", while some are based on the thinking of related issues and the interpretation of some fragments - the "why something is so" - which connect and synthesize the "so" and the "reasoning factors". Only the comprehensible, interpretable, and meaningful characteristics constituted by the "reasoning factors" and the "why something is so" can constitute a unit of thought. Likewise, only a thinking situation that can reasonably explain what is seen or constructed can constitute a unit of thought. Units of thought can be divided into three levels: "situational construction" [qingjing gouzuo 情境構作], “situational processing” [qingjing chuli 情境處理] and “situational fusion" [qingjing ronghe 情境融合]. See Lee Hsien-Chung 李賢中, “Mojia 'feigong' yu Shengjing youguan 'zhanzheng’ sixiang zhi bijiao 墨家‘非攻”與《聖經》有關‘戰爭'思想之比較 [A Comparison of Mohist Condemnation of Offensive Warfare and the Biblical Concept of War]," Zhexue yu wenhua 哲學與文化, no. 12 (2019): 5-23; see also Lee Hsien-Chung 李賢中, “Lun xianqin luojishi zhong daiyou sixiang neihan de tuili lüdong 論先秦邏輯史中帶有思想內涵的推 理律動 [The History of Pre-Qin Logic: A Reasoning Rhythm with Ideological Significance]," Hubei daxue xuebao 湖北大學學報, no. 1 (2018): 28-30. 
2. An explanation of the causal relationship (ethics, interest, power, structure, etc.) between things in the phenomenon, i.e., the situational processing of the unit of thought: Why?

3. A prediction of the future development of the phenomenon, i.e., situational processing of the unit of thought: What will happen?

4. A processing or resolution of issues found in the phenomenon, i.e., situational processing of the unit of thought: What can be done?

5. Periodic feedback, correction and integration after processing or resolving the issue, i.e., situational fusion of the unit of thought: The elements of "what is there", "what is it", "why", "what if" and "what should be done" are all in harmony with each other. ${ }^{8}$

This article will use the method of unit of thought in hermeneutics to analyze the two translators' conception of jian'ai by comparing common structural levels and analyzing the relationship between the various levels of theory and the elements of thinking in the unit of thought. It will be demonstrated that the reasoning factors of missionary-sinologists' translation of jian'ai are themselves a theoretical reconstruction of Mozi's 墨子 [ca. 468-376 вСE] ideas on jian'ai that have been imbued with modern significance. The specific issues that the author intends to address are as follows: What disagreements do the two translators have regarding the English translation of jian'ai? Furthermore, what do their translations reveal about their contrastive conceptions of jian'ai? Lastly, how can their differing interpretations of jian'ai be understood through the lens of the broader history of Western sinology?

Disputes regarding the Translation of Jian'ai into English

In 1859, Joseph Edkins translated jian'ai as "the doctrine of equal and universal" in his article about Mozi, with different wording employed in different contexts. For example, when quoting Mengzi's 孟子 [372-289 BCE] criticism of Mozi, he translated the term as "all men should be equally loved", while when discussing the significance of the concept he translated it as "mutual love". ${ }^{9}$ Edkins also elaborated on what he saw as the connotation of equality

8 Lee Hsien-Chung, "Mojia 'feigong' yu Shengjing youguan 'zhanzheng' sixiang zhi bijiao," 5-6.

9 Edkins wrote: "Only let men throughout the world love each other ... Why then does not every sage, whose business it is to explain how the world ought to be governed, adopt this principle and exhort men to mutual love?" Here, jian'ai is rendered as "mutual love" which demonstrates that Edkins also believed that such a concept can be described as "mutual". See Joseph Edkins, "Notices of the Character and Writings of Meh Tsii," Journal of the North China Branch of the Royal Asiatic Society, no. 2 (1859): 166. 
at the heart of jian'ai.Jian'ai is expressed as "universal love" in the source, with the term "equal" following thereafter, emphasized in italics. Edkins further posited that Mozi believed in the principle of not only loving one's neighbor as oneself but also loving all people equally. ${ }^{10}$

Two years later, fellow missionary Legge translated jian'ai as "universal love" in the second volume of his translated collection of Chinese classics. He also translated jian xiang ai 兼相愛 as "mutual love" and jiao xiang li 交相利 as "mutual benefit". Thus, it is evident that he believed that "mutual" could correspond to the meaning of jian 兼. As a result, he sometimes rendered jian xiang $a i$ as "universal mutual love" in his translation of the "Jian'ai" chapter."

In Legge's mind, it was necessary to limit the research object to understand the "equal" sense of universal love. Regarding discussion on this issue, he started from the standpoint of rebutting Mengzi:

Here it was that Mencius joined issue with him. He affirmed that "to love all equally did not acknowledge the peculiar affection due to a parent." It is to be observed that Mo himself nowhere says that his principle was that of loving all equally. His disciples drew this conclusion from it. In the third Book of Mencius' Works, we find one of them, Î Chih, contending that the expression in the Shû-ching, about the ancient kings acting towards the people "as if they were watching over an infant," sounded to him as if love were to be without difference of degree, the manifestation of it simply commencing with our parents. To this Mencius replied conclusively by asking, "Does Î really think that a man's affection for the child of his brother is merely like his affection for the child of his neighbour?" With still more force might he have asked, "Is a man's affection for his father merely like his affection for the father of his neighbour?" Such a question, and the necessary reply to it, are implied in his condemnation of Mo's system, as being "without father," that is, denying the peculiar affection due to a father. If Mo had really maintained that a man's father was to be no more to him than the father of any other body, or if his system had necessitated such a consequence, Mencius would only have done his duty to his country in denouncing him, and exposing the fallacy of his reasonings. As the case is, he would have done better if he had shown that no such conclusion necessarily flows from the doctrine of

$10 \quad$ Joseph Edkins, "Notices of the Character and Writings of Meh Tsï," 166.

11 James Legge, "Chapter III of Yang Chû and Mo Tî," in The Chinese Classics, ed. James Legge (Shanghai: Huadong shifan daxue chubanshe, 2010), 2:102-16. 
Universal Love, or its preceptive form that we are to love our neighbour as ourselves. ${ }^{12}$

Legge's discussion comes from a dialogue between Ruists and Mohists in the “Teng Wen Gong I 滕文公上” chapter of the Mengzi 孟子. A Mohist by the name of Yi Zhi 夷之 asked to see Mengzi. Mengzi first declined to meet him, but Yi Zhi persisted and came back a second time. However, before Mengzi met with him, he asked his student Xu Bi 徐辟 why Yi Zhi - a follower of Mohism and advocate of frugality - would give his parents a lavish burial. Here, Mengzi was accusing Yi Zhi of being unfilial towards his parents, or at the very least of departing from the ideals he espoused. Xu Bi relayed the Mengzi's message to Yi Zhi, who replied with the famous words: "According to the ways of the Ruists, the ancient rulers treated their people 'as if tending to new-born infants'. What do these words actually mean? I believe that there should be no graduations in love, though practicing it begins with one's parents." ${ }^{13} \mathrm{Xu}$ Bi then passed on $\mathrm{Yi}$ Zhi's sentiments to Mengzi, who responds by arguing that, although saving a baby who is about to fall into a well is an instinctive response of human nature in an emergency, this does not mean that under normal circumstances people can love their relatives and others without degrees of intimacy. One loves relatives more than others because one is born by one's parents. To remove the graduations of love is to equate one's parents with strangers which is contrary to the essential value system of Ruism. Legge clearly understood what Mengzi meant here. It was precisely because of Legge's his own beliefs and knowledge that he could point out how Mengzi's reasoning actually contained a kind of logical dilemma and some sort of ethical paradox.

Of course, this does not mean that Legge, like Edkins, accepted the completely opposite view of Mengzi, that is, that universal love is equal love. In fact, when he translated the title of "Jian'ai", he quoted the Shuowen jiezi 說文 解字 in the form of footnotes to discuss the meaning of jian in Chinese, claiming that it signified many different kinds of love. He went on to write that we was not sure if it would be better translated as "universal love", but ultimately conceded that Mengzi and other literati also regarded jian as "equal" and that, in their eyes, jian'ai was equivalent to the equal love of all. ${ }^{14}$ In Legge's understanding, the referents of jian may be more inclusive than equal. In the subsequent analysis, Legge gradually revealed a "truth": that the implication of

\footnotetext{
12 James Legge, "Chapter III of Yang Chû and Mo Tî," 2:101.

13 Jiao Xun 焦循, Mengzi zhengyi 孟子正義 [The Correct Meaning of the Mengzi], coll. Shen Wenzhuo 沈文倬 (Beijing: Zhonghua shuju, 1987), 403.

14 James Legge, "Chapter III of Yang Chû and Mo Tî," 2:101.
} 
the kind of universal love criticized by Mengzi was deduced at the beginning of creation. The so-called love of all people was a product of Mozi's later followers, and was not the point of view that Mozi himself had at the outset. This "historical" feature of this interpretation of jian'ai also raises a more important question: the core teachings of the Mozi are primarily expounded in chapters I, II and III. Do the differences in length and subtle changes in content also imply that the text has undergone a "historical" formative process? This issue has been overlooked by academics both in and outside of China. It was not until 1985 that A. C. Graham discussed the doctrinal differentiations of early Mohists and explored the relationship between the textual formation of the Mozi and the various Mohist factions. This is considered to be the first time the aforementioned issues have been explored, ${ }^{15}$ but a meaningful discussion of the historical issues pertaining to the text formation of the Mozi had not been had until they were raised by Erik W. Maeder in $1992 .{ }^{16}$ In the new century, Carine Defoort from the University of Leuven and the doctoral dissertations under her supervision have discussed these issues in some depth. ${ }^{17}$ Legge's discussions on the various meanings of jian'ai thus have had far-reaching implications for Mohist studies even up this the current century.

If a translated name [yiming 譯名] is the external manifestation of thought, then behind its coinage must lie a collection of thoughts. In the following section, the author will use the unit of thought as a way to analyze Edkin's conception of jian'ai.

\subsection{Edkins'Conception of Jian'ai as a Unit of Thought}

1. All the confusion that exists in the moral world, according to his system, springs from the want of love among men. From this origin come the

\footnotetext{
15 Augus Graham, Divisions in Early Mohism Reflected in the Core Chapters of Mo-Tzu (Singapore: Institute of East Asia Philosophies, 1985).

16 See Erik W. Maeder, "Some Observations on the Composition of the Core Chapters of the Mozi," Early China 17 (1992): 27-82.

17 See Carine Defoort and Nicolas Standaert, eds., The Mozi as an Evolving Text: Different Voices in Early Chinese Thought, vol. 4 of Studies in the History of Chinese Texts (Leiden: Brill, 2013). For the doctoral dissertation of Defoort's PhD student see Karen Desmet, "All Good Things Come in Threes: A Textual Analysis of the Three-fold Structure of the Mohist Ethical 'Core Chapters'” (PhD diss., Katholieke Universiteit Leuven, 2007).
} 
disobedience of sons and the unkindness of brothers. Robbery, oppression, rebellion, and all the evils depending on the perverse conduct of men that can afflict the commonwealth, proceed also from this source. If men loved their sons, brothers, and subjects as they do themselves, there would be no unkindness, no oppression. If a man esteemed his neighbour's house and his neighbour's person to be as precious as his own, he would not become a thief. Should men regard the inhabitants of other countries with the affection they bear to their own, there would be no war. Only let men throughout the world love, each other, and fighting and strife will cease; the father will love his son and the son be filial towards his father's oppression and rehellion will disappear, and perfect order be restored among the human race. Why then does not every sage, whose business it is to explain how the world ought to be governed, adopt this principle and exhort men to mutual love? 18

\section{Units of thought:}

1. What is there? There are evil acts such as unfilial piety, robbery, oppression, and rebellion. (This is a description of a series of phenomena and issues.)

2. What is it? It is suffering in the world. (This is a conclusion based on the aforementioned human suffering, and it is related to people's feelings about the phenomenon, which positions the description of the phenomenon.)

3. Why is that? Because of a lack of jian'ai. (This is a conclusion based on the aforementioned idea that all confusion that exists in the moral world stems from a lack love between people and the reason behind the related phenomenon.)

4. What would happen if jian'ai were practiced? There would be no unkindness or oppression. (According to the rationale that if men loved their sons, brothers, and subjects as they do themselves, there would be no unkindness, no oppression, and eventually there would be no potential for war either.)

5. What should be done? The world must be governed with jian'ai and its precepts should be promoted. (A solution to the problem is offered.)

2. In advocating universal love, this philosopher lays great stress on the circumstance that it should be equal towards all. He observes that when men begin to distinguish between one man and another, hatred and

18 Joseph Edkins, "Notices of the Character and Writings of Meh Tsï," 166. 
injustice make their appearance. The right principle is, he contends, to love others as we do ourselves, and to love all equally. We are not to make a distinction in love between another kingdom and our own. He would have men feel as much desire that their neighbor should not be robbed of his property as that they themselves may not suffer in that manner. ${ }^{19}$

\section{Units of thought:}

1. What is there? Hatred and injustice exist.(The phenomenon is described.)

2. What is it? It is an improper method. (The correct principle is to love others as one loves oneself.)

3. Why is that? Because people make distinctions of others. (This is the reason behind the phenomenon.)

4. What will happen? Hatred and injustice will emerge. (This is in line with the development of the phenomenon.)

5. What should be done? One should love others as one loves oneself, and love everyone equally. (Here the solution to the problem is provided.)

3. The coincidence here with the doctrine of love in the New Testament is surely not a little remarkable, especially as found in the extant works of an author who lived in China four or five centuries before the Christian era. Strange it is that such a doctrine should have been proposed in China so long ago and rejected.

There are, however, some important differences in the form given to this doctrine by Meh tsii. He bases it upon political utility, while our Saviour rests the obligation to love on religious and moral grounds. The Christian is to love in obedience to the will, and in imitation of the example, of God. Meh tsï, moreover, does not say, "love your enemies." His view is too utilitarian for this; the highest point reached by him is, if you love me as I love you, we shall both be the better for so doing. The apostle John describes love as a spontaneous activity, flowing from a heart touched with gratitude. We love him, because he first loved us." I am to love my brother man, because Christ died for him as for me. Our Chinese philosopher knew nothing of such an origin for his favorite principle, deep among the foundations of our moral and emotional nature. His views, while resembling Christianity in form, are much more akin in reality to the opinions of Bentham and Paley, who, had he lived in their day, would doubtless have claimed him as an ally. ${ }^{20}$

19 Joseph Edkins, "Notices of the Character and Writings of Meh Tsii," 167.

20 Joseph Edkins, "Notices of the Character and Writings of Meh Tsï," 167-68. 
Units of thought:

1. What is there? Mozi's jian'ai takes a similar form to that of the doctrine of love in the New Testament.

2. What is it? It is a different theoretical basis. (This is a description of the phenomenon, and the essence behind the phenomenon.)

3. Why is that? The foundation of jian'ai is political utility while the love of Jesus is based on religion and morality. (This touches upon the social setting, ethics, personal interests and many other factors involved in the problem.)

4. What will happen? "If Mozi lived in their time, they would undoubtedly regard him as an ally." (This conforms with the development of the logic.)

5. What should be done? A distinction must be made between jian'ai and the love of Christ. (This is in accordance with the aforementioned idea that, although his views are similar to Christianity in form, in reality they are closer to the views of Bentham and Paley. Here, a solution to the problem is provided.)

\subsection{General Idea behind Edkins' Conception of Jian'ai}

It can be seen that the unit of thought is a specific and effective hermeneutical method by which a problem can be made clearer and more logical. Based on the analysis of the above units of thought, the author will now discuss the overall thinking behind Edkins' conception of jian'ai. As Lee Hsien-Chung pointed out, "Theories are composed of units of thought, while the scopes of those theories are broader than the units of thought that reside in them". ${ }^{21}$ Therefore, considering the relative completeness of a given theory, the following thoughts on Edkin's conception of jian'ai will touch upon other passages from his writings.

Why did Mengzi criticize Mozi? Mozi's proposal of jian'ai is a departure from the love of his parents. Furthermore, Mengzi believed that this was an attack on Confucius' [551-479 $\mathrm{BCE}$ ] integrity and his doctrines. $\rightarrow$ What is jian'ai? Jian'ai posits that loving everyone equally is a broad principle that can maintain order in a given state. $\rightarrow$ Why does Mozi advocate jian'ai? There are various evils in society such as robbery, oppression, rebellion, hatred and injustice. $\rightarrow$ What are the consequences of a lack of jian'ai? It will cause disputes and wars. $\rightarrow$ What is the purpose of practicing jian'ai? People will love each other and society will be restored to perfect order. $\rightarrow$ Is there any concept of jian'ai in the Western world? Yes, there is. The doctrine of love in the New Testament is very similar to it. $\rightarrow$ Is the concept of jian'ai identical to that of the love of

21 Lee Hsien-Chung, "Mojia 'feigong' yu Shengjing youguan 'zhanzheng' sixiang zhi bijiao," 9. 
Christ? No. There are theoretical flaws in the conception of jian'ai. $\rightarrow$ What is the problem with the conception of jian'ai? Since jian'ai is constructed on the basis of political utility, it completely ignores the religious, moral, and emotional basis of Christ's love. $\rightarrow$ How should jian'ai be understood? In essence, jian'ai is closer to the idea of utilitarianism. ${ }^{22}$

The discussion outlined above attempts to present Edkins' thoughts on reconstructing the idea of jian'ai in a deductive way. If analyzed from various levels of theory, the situational construction of the significance of jian'ai starts with Mengzi's criticism of Mozi and extends to Mozi's pursuit for the most suitable principle for establishing order in a given state. It is believed to be developed by loving all people equally in order to resolve the moral chaos present in the society in which one lives. In terms of situational processing, the concept of jian'ai espoused by Mozi emphasized the equality of all people, which conflicted with traditional Chinese morality, especially filial piety, and resulted in all later advocates of jian'ai to be regarded as heretics. In fact, Mozi believed that the key embodiment of jian'ai is not only found in the benevolent ruler, but should also be seen in the fulfilling of duties by ordinary people. He also concluded that widespread practice of jian'ai would bring peace to the world. In terms of situational fusion, Edkins believed that Mozi's jian'ai makes its appearance in Western thought and theology, and that the coincidental elements of jian'ai and the love of Christ can be made manifest after careful investigation. The two are mainly similar in form, while jian'ai lacks the theoretical foundations of theology and morality. As far as the motivation of jian'ai is concerned, it is closer to utilitarianism, but in any case, jian'ai should be valued even outside the Ruist cosmology. ${ }^{23}$

22 Upon reviewing the author's work, Lee Hsien-Chung has explained via email correspondence that, "Edkins' belief that universal love is closer to utilitarianism reflects but one aspect of Mohism. From the perspective of Heaven's Intention, Righteousness, and Proactive Loving of Others in Spite of Non-Accomplishment one can see the staunch belief of the Mohists that individuals should act in accordance with the ways of Heaven, and that doing so is advantageous to them." There is little room here to discuss the numerous debates both in and outside of China on the relationship between jian'ai and utilitarianism. For a review on this topic, see Nie Tao 聶濤, “Zhaoshi yu liubian: Jinshi mozi sixiang de gongli zhuyi chanshi de zhongxi chengqi 肇始與流變：近世墨子思想的功利主義 闡釋的中西承啓 [Beginnings and Evolutions: The Utilitarian Interpretation of Mohist Thought in Modern Times]," Shehui kexuejia 社會科學家, no. 8 (2016): 22-6. Joseph Edkins, "Notices of the Character and Writings of Meh Tsï, 166-9. 


\section{Legge's Conception of Jian'ai}

\subsection{Units of Thought Contained in Legge's Conception of Jian'ai}

Legge's reconstruction of jian'ai can also be clearly seen through the unit of thought. The following discussion will reflect on the unit of thought through the lens of Legge's interpretation of Mozi.

1. Still, he has broadly and distinctly laid it down, that if men would only universally love one another, the evils which disturb and embitter human society would disappear. I do not say that he has taught the duty of universal love. His argument is conducted on the ground of expediency. Whether he had in his own mind a truer, nobler foundation for his principle, does not immediately appear. Be that as it may, his doctrine was that men were to be exhorted to love one another, to love one another as themselves. According to him, "princes should be as much for the States of others as for their own. One prince should be for every other as for himself." So it ought to be also with the heads of clans, with ministers, with parents, and with men generally. ${ }^{24}$

\section{Units of thought:}

1. What is there? There are Mozi's precepts of jian'ai. (As a translator and interpreter of the Chinese classics, Legge described the object of Mozi's jian'ai and identified its essential nature.)

2. What is it? It is borne out of the consideration of one's own interests.

3. Why is that? As long as people love each other, social evils will disappear. Individuals can also benefit. (Legge's reason for exploring this is that his discussion is based on his own interests.)

4. What will happen? Practicing jian'ai will restore social stability.

5. What should be done? One should practice jian'ai and love others as one would love oneself. (As discussed previously, princes should be as much for the states of others as for their own, and so the same should be said for clan leaders, ministers, parents, and individuals. Here, Legge provides a solution to the problem.)

2. Confucius, I think, might have dealt more fairly and generously with Mo. In writing of him, I called attention to his repeated enunciation of "the golden rule" in a negative form, - "What you do not wish done to yourself, do not do to others." In one place, indeed, he rises for a moment

24 James Legge, "Chapter III of Yang Chû and Mo Tî," 2:117-8. 
to the full apprehension of it, and recognizes the duty of taking the initiative, of behaving to others in the first instance as he would that they should behave to him. Now, what is this but the practical exercise of the principle of universal love? "All things whatsoever ye would that men should do to you, do ye even so to them" - this is simply the manifestation of the requirement, "Thou shalt love thy neighbour as thyself." Confucius might have conceded, therefore, to Mo, that the rule of conduct which he laid down was the very best that could be propounded. If he had gone on to remove it from the basis of expediency, and place it on a better foundation, he would have done the greatest service to his countrymen, and entitled himself to a place among the sages of the world. ${ }^{25}$

Units of thought:

1. What is there? Something similar to jian'ai can be found in the teachings of both Confucius and Christ. (Here, questions are extracted from the examined phenomena.)

2. What is it? Expressions resembling jian'ai are present in Ruist and Christian doctrine alike. (There may not be a conflict between Kongzi's ren'ai and Mozi's jian'ai. One can look beyond the surface of the phenomenon by considering the common notion of treating others how one wishes to be treated that was previously discussed.)

3. Why is that? Legge compared the teachings of Kongzi, Mozi, and Jesus and concluded that if Mozi were to replace his concept of self-interest with a better theoretical foundation, then he would have made a great contribution to Chinese thought and secure his place among the sages of the world.

4. What will happen? Legge believed it necessary to remove the consideration of jian'ai that is based on self-interest.

5. What should be done? Mohist thought would have a greater influence on the world.

3. Mo's universal love was to find its scope and consummation in the good government of China. He had not the idea of man as man, any more than Confucius or Mencius. How can that idea be fully realized, indeed, where there is not the right knowledge of one living and true God, the creator and common parent of all? The love which Christianity inculcates is a law of humanity; paramount to all selfish, personal feelings; paramount to all relative, local, national attachments; paramount to all distinctions of race 
or of religion. Apprehended in the spirit of Christ, it will go forth even to the love of enemies; it will energize in a determination to be always increasing the sum of others' happiness, limited only by the means of doing so. But I stop. These prolegomena are the place for disquisition; but I deemed it right to say thus much here of that true, universal love, which at once gives glory to God and effects peace on earth. ${ }^{26}$

Units of thought:

1. What is there? There is the concept of jian'ai that is used for governance purposes.

2. What is it? Jian'ai is not about being human. (This is the essence of jian'ai.)

3. Why is that? Mozi's jian'ai lacks a kind of transcendent divinity. (This is based on the aforementioned idea that one cannot fully realize one's ideals without a proper understanding of the true living God, the creator and the common father of all people.)

4. What will happen? Jian'ai cannot surpass Confucius and Mengzi; it will be confined to the fetters of human nature, politics and secularity.

5. What should be done? To bring about peace, the love of Christ must be espoused. (This is the true manifestation of jian'ai.)

\subsection{General Idea behind Legge's Conception of Jian'ai}

After summarizing Legge's research on jian'ai from the perspective of the unit of thought, the following will discuss Legge's overall thinking on the concept. In order to outline a relatively complete picture of the theory, the author will consult Legge's writings on Mozi in their entirety.

Why did Mengzi oppose Mozi? It was the result of a struggle between different schools of thought. ${ }^{27} \rightarrow$ How does Mozi defend himself? Because Yu the Great 大禹, Tang of Shang 商湯, King Wen of Zhou 周文王 [r. 11061056 в С ], and King Wu of Zhou 周武王 [r. 1056-1043 В СE] all practiced jian'ai. $\rightarrow$ Did these ancient sages actually put jian'ai into practice? No. The first piece of Mozi's evidence is not valid. $\rightarrow$ Does fear of punishment really motivate people to practice jian'ai? No. The second piece of Mozi's evidence is not valid. $\rightarrow$ Why should one practice jian'ai? To resolve the ills of society. $\rightarrow$ So does that mean that the theoretical basis of jian'ai is the duty of love? No, it is but

26 James Legge, “Chapter III of Yang Chû and Mo Tî,” 2:122.

27 Legge translated the three chapters on jian'ai to explore its philosophical implications and understand why it attracted such fierce criticism from Mengzi. To this end, he included an analysis on the subject directly after his translation. See James Legge, "Chapter III of Yang Chû and Mo Tî," 2:117. 
the individual's self-interest. $\rightarrow$ What theory can persuade people to practice jian'ai? One should love others as one would love oneself; one should love the states of others as one would love one's own state. $\rightarrow$ What is the scope of application of jian'ai? People of all levels and groups of society can follow it. $\rightarrow$ Does this mean that jian'ai is to love all people equally? No, Mengzi misinterpreted Mozi's teachings. $\rightarrow$ Then why did Mengzi criticize Mozi's conception of love for lacking differentiation? This is the view of Mozi's followers, not his own viewpoint. In fact, the evidence we can see today comes from the debate between Mengzi and Yi Zhi in "Teng Wen Gong I". $\rightarrow$ Is there sufficient evidence for Mozi to defend his views? No. He merely emphasized that a person can only ensure happiness for his parents by practicing jian'ai. $\rightarrow$ Does this show that there is something wrong with Mozi's theory? Mozi only considers the basis of love from the point of interest, and Mengzi's discussion on the issues of human nature and moral restraint is broader and more precise than that of Mozi. $\rightarrow$ What do Mengzi and Mozi think about the dispute about love? Mozi accidentally discovered the true significance of jian'ai, which is of considerable significance to human society in that it can enrich the mind and provide the most reliable treatment for social ills. However, Mengzi could not accept it because he felt it was difficult to implement. He even absurdly compared Yang Zhu 楊朱 [395-335 BCE] and Mozi, presupposing them as enemies of humaneness and righteousness [renyi 仁義]. Therefore, there is a kind of ruthlessness to Mengzi's conception of human nature. $\rightarrow$ How would Confucius view the concept of jian'ai? Confucius would accept Mozi, because jian'ai can be interpreted in a way that is similar to that of the Confucian equivalent to the Golden Rule. $\rightarrow$ In "our religion" are there any thoughts similar to that of universal love? Yes. Christ's Golden Rule has a roughly similar meaning. $\rightarrow$ Is this the first time such a view has been held on jian'ai? No, the Tang [618-907] writer Han Yu 韩愈 [768-824] once argued that "the thought of Confucius and Mozi can be used simultaneously". In fact, our views are the same. $\rightarrow$ How is the love of Christ compared to jian'ai? The love of Christ is based on a kind of transcendent divinity. As a commandment, it requires that people must first love God. Therefore, Christianity requires everyone to dedicate themselves to loving God. From this love, each person's specific responsibilities are further clarified. Complementing the love of God and one's fellow citizens and loving others as loving oneself are practiced under this premise. $\rightarrow$ Is there any real jian'ai? Yes. $\rightarrow$ What is it? It is the love of Christ that brings glory to God and realizes peace in the world. ${ }^{28}$ 
Let us turn now to the situational construction of the concept of jian'ai. In his critique of Mengzi's opposition to Mozi, Legge perceived jian'ai as a tool to overcome the kinds of evil that harm society. In terms of situational processing, Legge's textual analysis of "Teng Wen Gong I" revealed that Mozi himself did not approve of loving all people equally. However, Mozi focused on selfinterest in the theoretical construction of his own argumentation, and failed to find a deeper and broader theoretical basis. In this regard, one can use the respective doctrines of Confucius and Christ to enact situational fusion with Mozi's thought - from within Chinese thought, Confucius may understand and tolerate the teachings of Mozi, while outside Chinese thought, the love of Christ and the conception of universal love bear superficial resemblance to each other. Of course, after careful study and comparison, one may find that the love of Christ has transcendent divine value and loving one's neighbor as one loves oneself is actually an extension of the love of a supreme God. Therefore, the love of Christ can be seen as a kind of true universal love. ${ }^{29}$

\section{5}

\section{Shift from Amateur to Professional Sinologists}

The author has used the interpretative method of the unit of thought to understand the different translations and interpretations of jian'ai by Edkins and Legge. It presents a logic of thought that spans the discovery of the problem to the offering of a solution. An examination of the respective scholarly interests of Edkins and Legge reveals their differing interpretations of "equality" as it relates to jian'ai and in their capacity as missionaries to China in midnineteenth century. As an amateur sinologist, Edkins was stationed in China to introduce the traditional ideas and modern conditions of China to the Western world, as well as to acquaint China with knowledge from the West. Legge was both a colleague and old acquaintance of Edkins. The two of them devoted an increasing amount of energy to academic research over the years. ${ }^{30}$ Legge embarked on a professional study of the Chinese civilization, assuming the new Chair of Chinese Language and Literature at Oxford in 1876 . From the perspective of the historical development of the field of sinology, this professional

29 See James Legge, "Chapter III of Yang Chû and Mo Tî," 2:117-22.

30 Norman J. Girardot 吉瑞德, Chaojin Dongfang: Li Yage pingzhuan 朝唓東方: 理雅各 評傳 [The Victorian Translation of China:James Legge's Oriental Pilgrimage], trans. Duan Huaiqing 段懷清 and Zhou Liling 周俐玲 (Guilin: Guangxi shifan daxue chubanshe, 2011), 82 . 
dispute between the two missionaries came to a head when they began forming their interpretation of the concept of jian'ai around 1860.

Edkins was a well-deserved sinologist among the missionaries who came to China in the 19th century. He graduated from the University of London in his early years and received fairly good training in modern scientific knowledge. According to the archives of the University, in addition to Greek, Latin, and Hebrew, he also majored in mathematics and botany, natural philosophy and philosophy of mind and logic, and graduated from the institution with a Bachelor of Arts. After arriving in Shanghai in 1848, he immediately devoted himself to The London Missionary Society Press, known in Chinese as Mohai shuguan 墨海書館 by participating in translation work aimed at introducing modern Western scientific works to a Chinese-reading audience. After 1861, he travelled north to devote himself to missionary work in Tianjin and Beijing. He served as a bridge in a specific period of Early Modern [jindai zaogi 近代早期] Chinese history ${ }^{31}$ by gradually contributing to the two-way knowledge transfer between the East and the West. He not only introduced Western science to Chinese scholar-officials, but introduced humanistic knowledge to them as well. The earliest Greek and Roman history that can be sighted in modern Chinese sources are $A$ Brief History of Greece [Xila zhilüe 希臘志略] and A Brief History of Rome [Luoma zhilüe 羅馬志略] from the Western Learning Book Series [Xixue qimeng congshu 西學啟蒙叢書] that were both translated by Edkins. He also introduced Chinese thought to the Western world, from Buddhist and Daoist philosophy, to geography, language and history, as well as all kinds of aspects of contemporary China of the time such as taxation, currency, and finance. ${ }^{32}$ Edkins' scholarly interest in China was so wide-ranging that it can be seen as a vivid portrayal of a distinctive feature of the history of European sinology in the 18th and 19th centuries, as at that time all knowledge about China was generated by the expertise of sinologists.

Edkins was proficient in Chinese, being not only familiar with northern Mandarin, but also with Shanghainese. In contrast, Legge, who had lived in

31 How this period should be delineated has long been controversial among historians. The author here is referring to the period of 1840-1895, which reflects the general understanding of Western learning among the Qing gentry at the time.

32 On Edkins' contributions as a sinologist, see the third part ("Missionaries as Modern Scholars and the Transfer of Chinese and Western Knowledge") of the author's work: Chu Lijuan 褚麗娟, “Wanqing chuanjiaoshi: Hanxuejia Ai Yuese de Moxue sixiang chutan 晚清傳教士: 漢學家艾約瑟的墨學思想初探 [A Preliminary Study on the Mohist Thought of Missionary: Sinologist Joseph Edkins in the Late Qing Dynasty]," Zhexue yu wenhua 哲學與文化, no. 12 (2019): 63-78. See also Yu Manyi 喻滿意, “Ai Yuese yu 19 shiji yingguo de hanxue 艾約瑟與 19 世紀英國的漢學 [Joseph Edkins and Sinology in England in the 19th Century]" (PhD diss., Nankai University, 2015). 
Hong Kong for a long time, may have been able to meet his research needs in the written language, but his spoken command left something to be desired. Before returning to England in 1873, Legge embarked on a journey to northern China. During part of the tour he was accompanied by Edkins who had been living in northern China for a long time and was able to speak fluent Mandarin, a feat Legge was incapable of replicating. ${ }^{33}$

Evidently, Legge's shortcomings in oral Chinese did not prevent him from becoming the preeminent sinologist in the Western world after the 1870s. After the publication of his five-volume classics work in 1861, it has been republished many times so far, and it is a well-deserved classic in English translation. With the death of the renowned French sinologist Stanislas Julien [1797-1873], Legge became the only translator and interpreter of the most influential Chinese classics in the Western world. ${ }^{34}$ His achievements were recognized by his fellow scholars at the time. Max Müller [1823-19oo], the head of the Faculty of Oriental Studies at Oxford, hired him as the first professor of sinology. The appointment of Legge to this post also meant that, over the previous two centuries, the European sinological community shifted its focus from research in Latin and French to research in the English language. In addition, the translation work for the Sacred Books of the East series that Müller presided over was mainly undertaken by Legge. This set of works, together with Legge's translation of the Chinese classics during his stay in Hong Kong, served as the greatest academic project in the translation of Chinese classics and comparative oriental studies at the end of the 19th century, and has had widespread impact since then, with sinology thereafter gaining recognition in the Western academe as a specialized field of oriental studies. ${ }^{35}$

Legge was a professional sinologist. His depth and breadth of understanding of the Chinese classics had already formed by the time he relocated to Hong Kong, and his dedication to academic rigor is undeniable. In order to translate the core texts that expound the values and belief systems of Ruism known as the Four Books [sishu 四書] he hired a research assistant by the name of Wang Tao 王鞱 [1828-1897]. When translating the Mengzi, he specially translated the three chapters on jian'ai and some of the teachings of Yang Zhu. It can be said that this was a response to Mengzian thought based on the Chinese system of scholarship. Naturally, Legge's perspective on Chinese scholarship may not have been fully formed during the Hong Kong period, but its embryonic

33 Edkins arrived in Tianjin in 1861 and began his missionary work in Beijing in 1863.

34 Norman J. Girardot, Chaojin Dongfang: Li Yage pingzhuan, 57.

35 Norman J. Girardot, Chaojin Dongfang: Li Yage pingzhuan, 121. 
form had already appeared.$^{36}$ As a 19th-century sinologist who accepted modern knowledge, his perspective served to illuminate the thought of Mozi. Under the strong influence of Western learning, the Chinese tendency towards modernity gradually grew in intensity, especially after 1895 when the gentry of the late Qing dynasty [1616-1911] experienced rapid ideological shifts and Western learning increased in popularity. It was in this historical context that a resurgence in research on Mohist thought occurred.

The broad learning of traditional sinology is vividly reflected in Edkins. Judging from his works, he does not seem to have the same perspective that would enable him to understand the Chinese classics like Legge did. Moreover, it would have been unrealistic to have expected him to interpret the Chinese classics from the perspective of the Chinese scholarly tradition. His understanding of jian'ai was more based on his external perspective as a British missionary-sinologist. Therefore, he integrated the implications of "equality" into his interpretation of jian'ai, something which Legge could not accept. A detail that is easily overlooked is that Legge quoted in one of his footnotes that Edkins pointed out the similarities of utilitarianism to jian'ai. However, he did not express disagreement with Edkin's point of view in his translation of jian'ai, choosing instead to write at length about whether jian'ai could be interpreted in this manner. This may suggest that Legge felt it inappropriate to point out Edkins' "mistake", deciding instead to merely express his different understanding. It can also be seen that Legge's discussion of jian'ai was based on rigorous academic research with a view to its history of scholarship. As a result, Edkins and Legge differ on whether jian'ai carries a connotation of "equal".

36 On this point, it may be possible to identify one or two changes in Legge's attitude towards Confucius and Ruism at different periods; see, for example, Norman J. Girardot, Chaojin Dongfang: Li Yage pingzhuan, 87. It is also noteworthy that Legge did not necessarily accept all of Wang Tao's opinions during his translation process. Reading his translations, it is clear that he deployed critical thinking when he encountered sources with differing interpretations. There has been a mushrooming of research on Leggian interpretation of the Chinese classics in recent years. For instance, see Shi Jinghuan 史靜寰 and Wang Lixin 王立新, Jidujiao jiaoyu yu Zhongguo zhishi fenzi 基督教教育與中國知識 分子 [Christian Education and Chinese Intellectuals] (Fuzhou: Fujian jiaoyu chubanshe, 1998); Yue Feng 岳峰, “Guanyu Li Yage yingyi Zhongguo gujing de yanjiu zongshu:Jianlun kuaxueke yanjiu fanyi de biyaoxing 關於理雅各英譯中國古經的研究綜述: 兼論跨 學科研究翻譯的必要性 [Studies on James Legge's English Translation of Traditional Chinese Classics and Reflections on the Necessity of the Interdisciplinary Approach in Translation Studies]," Jimei daxue xuebao 集美大學學報, no. 2 (2004); Shi Kai 史凱, “Li Yage Zhongguo jingdian fanyi shulüe 理雅各中國經典翻譯述略 [On James Legge's Translation of the Chinese Classics]," Fanyi yu wenhua 翻譯與文化, no. 3 (2015). 
The respective translations of jian'ai by Edkins and Legge, as well as their discussion of its conception, are essentially a cross-cultural reconstruction. As translators, their identity is not only informed by their role as 19th century missionary-sinologists. Their opinions on Chinese civilization and Sino-British relations as revealed in their public speeches and interactions with Chinese officials clearly reveal another function they had as members of the British intelligentsia of the Victorian era [1837-19o1]. These identities constitute their cognitive background that came into play when they translated the concept of jian'ai. In the first half of the 2oth century, other missionaries travelled to China such as Henry Raymond Williamson [1883-1966], Sverre Holth [19021993] and Frank Joseph Rawlinson [1871-1937]. In their respective works ${ }^{37}$ can be found various translations of jian'ai into English which all more or less accept the interpretation of its senses of equality and universality, sometimes even using other renderings such as "undiscriminating love" or "indiscriminating love", "impartial love" and "love without distinction". According to the evolutionary history of the English lexicon, it can be understood that the use of the term "equal" reflects the ideological spirit of the 19th century, while after the 2oth century words such as "undiscriminating" and "impartial" were usually associated with issues such as racial prejudice. It can be seen from this that the missionary-sinologists who came to China from the late Qing to the Republican Era [1912-1949] enacted interpretations based on their pre-existing system of knowledge and projected their prescriptive expectations on their reconstruction of the concept of jian'ai. However, due to space limitations, the author will not delve further into this complex issue, but instead wishes to explore it in a future research project.

It is also noteworthy that the most commonly used translation of jian'ai in the Anglosphere is "universal love", which was popularized by Legge. This is a fact that should not be overlooked. A historical overview of the literature can reveal how the translation of jian'ai has been explored from the perspectives of textual understanding and theoretical reconstruction. Compared with contemporary Chinese scholar-officials, similar understandings were not expressed until the publication of The Ideas of Mozi [Zimozi xueshuo 子墨子 學說] by the renowned intellectual Liang Qichao 梁啓超 [1873-1929] in 1904.

37 Henry R. Williamson, Moti, A Chinese Heretic (Tsinan: The University Press, 1927); Sverre Holth, Micius: A Brief Outline of His Life and Ideas (Shanghai: The Commercial Press, 1935); Frank Rawlinson, "The Ethical Values of Micius," The Chinese Recorder and Missionary Journal, Feb (1932). 
From a diachronic perspective that examines the "discovery" of the modern dimensions of Mohist thought, the author concludes that the research of the two missionary-sinologists was pioneering work ${ }^{38}$ and their modern reconstruction of jian'ai can be considered to have been a breakthrough.

\section{Translated by Carl Gene Fordham}

\section{Works Cited}

Chu Lijuan 褚麗娟. “Wanqing chuanjiaoshi: Hanxuejia Ai Yuese de Moxue sixiang chutan 晚清傳教士一漢學家艾約瑟的墨學思想初探 [A Preliminary Study on the Mohist Thought of Missionary: Sinologist Joseph Edkins in the Late Qing Dynasty]." Zhexue yu wenhua 哲學與文化, no. 12 (2019): 63-78.

Defoort, Carine and Nicolas Standaert, eds. The Mozi as an Evolving Text: Different Voices in Early Chinese Thought. Vol. 4 of Studies in the History of Chinese Texts Leiden: Brill, 2013.

Deng Chun 鄧春. "Cong shendu fanyi de shijiao duibi fenxi Mozi liubu yingyiben: Yi 'jian'ai shang zhong xia' de yingyi wei li 從深度翻譯的視角對比分析《墨子》 六部英譯本一以“兼愛(上、中、下)’的英譯為例 [A Comparative Analysis of Six English Versions of the Mozi from the Perspective of Thick Translation, Taking the Translation of 'Jian'ai I, II, III' as an Example].” Waiyu jiaoyu yanjiu 外語教育研究, no. 2 (2015): 64-71.

Desmet, Karen. "All Good Things Come in Threes: A Textual Analysis of the Three-fold Structure of the Mohist Ethical 'Core Chapters." PhD diss., Katholieke Universiteit Leuven, 2007.

Edkins, Joseph. "Notices of the Character and Writings of Meh Tsii." Journal of the North China Branch of the Royal Asiatic Society, no. 2 (1859): 165-69.

Gao Yuanyuan 高媛媛. “Fanyi guifanlun shijiao xia Mozi yingyi duibi yanjiu 翻譯規範 論視角下《墨子》英譯對比研究 [A Comparative Study of the English Translations of the Mozi from the Perspective of Translation Norm Theory]." Jiaoyu xiandaihua 教育現代化, no. $5^{1}$ (2017): 294-5.

Girardot, Norman J. 吉瑞德. Chaojin Dongfang: Li Yage pingzhuan 朝覲東方: 理雅 各評傳 [The Victorian Translation of China: James Legge's Oriental Pilgrimage]. Translated by Duan Huaiqing 段懷清 and Zhou Liling 周例玲. Guilin: Guangxi shifan daxue chubanshe, 2011.

38 There is currently a trend among academics to discuss Western interpretations of Mohist doctrine. It is easier to point out their misunderstandings of Mohism and in turn ignore the ideological tendencies expressed by these studies themselves. 
Graham, Angus. Divisions in Early Mohism Reflected in the Core Chapters of Mo-Tzu. Singapore: Institute of East Asia Philosophers, 1985.

Holth, Sverre. Micius: A Brief Outline of His Life and Ideas. Shanghai: The Commercial Press, 1935 .

Jiao Xun 焦循. Mengzi zhengyi 孟子正義 [The Correct Meaning of the Mengzi]. Collated by Shen Wenzhuo 沈文倬. Beijing: Zhonghua shuju, 1987 .

Lee, Hsien-Chung 李賢中. “Mojia 'feigong' yu Shengjing youguan 'zhanzheng' sixiang zhi bijiao 墨家‘非攻”與《聖經》有關‘戰爭’思想之比較 [A Comparison of Mohist Condemnation of Offensive Warfare and the Biblical Concept of War]." Zhexue yu wenhua 哲學與文化, no. 12 (2019): 5-24.

Lee, Hsien-Chung 李賢中. "Lun xianqin luojishi zhong daiyou sixiang neihan de tuili lüdong 論先秦邏輯史中帶有思想內涵的推理律動 [The History of Pre-Qin Logic: A Reasoning Rhythm with Ideological Significance]." Hubei daxue xuebao 湖北大學 學報, no. 1 (2018): 28-30.

Legge, James. “Chapter III of Yang Chû and Mo Tî.” In The Chinese Classics, edited by James Legge, 2:10o-22. Shanghai: Huadong shifan daxue chubanshe, 2010.

Liao Zhiyang 廖志陽. “Mozi yingyi gaiguan《墨子》英譯概觀 [A Brief English Translation History of the Mozi]." Zhongnan daxue xuebao 中南大學學報, no. 2 (2013): 232-36.

Liu Lisheng 劉立勝. “Mozi fuyi yu yizhe huayuquan jiangou celüe bijiao yanjiu 《墨子》 複譯與譯者話語權建構策略比較研究 [A Study on the Retranslations of the Mozi and Translators' Discourse Power Constructing Strategies].” Zhejiang waiguoyu xueyuan xuebao 浙江外國語學院學報, no. 1 (2017): 75-81.

Maeder, Erik W. "Some Observations on the Composition of the Core Chapters of the Mozi." Early China 17 (1992): 27-82.

Miao Xuemei 苗雪梅. “Mozi yingyiben zhong de wenben wushi yu fanyi celüe《墨子》英 譯本中的文本誤釋與翻譯策略 [Text Misinterpretations and Translation Strategies in English Versions of the Mozi]." Hebeiguangbo dianshi daxue xuebao 河北廣播電 視大學學報, no. 2 (2013): 6o-3.

Nie Tao 聶濤. "Zhaoshi yu liubian: Jinshi mozi sixiang de gongli zhuyi chanshi de zhongxi chengqi 肇始與流變: 近世墨子思想的功利主义阐释的中西承启 [Beginnings and Evolutions: The Utilitarian Interpretation of Mohist Thought in Modern Times]." Shehui kexuejia 社會科學家, no. 8 (2016): 22-6.

Rawlinson, Frank. "The Ethical Values of Micius." The Chinese Recorder and Missionary Journal, Feb (1932): 93-102.

Shi Jinghuan 史靜寰 and Wang Lixin 王立新.Jidujiaojiaoyuyu Zhongguo zhishifenzi 基 督教教育與中國知識分子 [Christian Education and Chinese Intellectuals]. Fuzhou: Fujian jiaoyu chubanshe, 1998.

Shi Kai 史凱. “Li Yage Zhongguo jingdian fanyi shulüe 理雅各中國經典翻譯述略 [On James Legge's Translation of the Chinese Classics]." Fanyi yu wenhua 翻譯與 文化, no. 3 (2015): 147-52. 
Wang Hong 王宏. “Mozi yingyi duibi yanjiu《墨子》英譯對比研究 [A Study Comparing the Various English Translations of the Mozi]." Jiefangjun waiguoyu xueyuan xuebao 解放軍外國語學院學報, no. 6 (2006): 55-6o.

Williamson, Henry R. Moti, A Chinese Heretic. Tsinan: The University Press, 1927.

Xu Bin 徐斌, Wang Jiali 王佳莉 and Yi Fang 易芳. “Duo motai shiyu xia Mozi yingyi tanxi 多模態視域下《墨子》英譯探析 [An Analysis of the English Versions of the Mozi from the Perspective of Multimodality]." Chuangxin chuangye lilun yanjiu yu shijian 創新創業理論研究與實践, no. 17 (2020): 151-3.

Yu Manyi 喻滿意. “Ai Yuese yu 19 shiji yingguo de hanxue 艾約瑟與19世紀英國的 漢學 [Joseph Edkins and Sinology in England in the 19th Century]." PhD diss., Nankai University, 2015.

Yue Feng 岳峰. “Guanyu Li Yage yingyi Zhongguo gujing de yanjiu zongshu: Jianlun kuaxueke yanjiu fanyi de biyaoxing 關於理雅各英譯中國古經的研究綜述一兼論跨 學科研究翻譯的必要性 [Studies on James Legge's English Translation of Traditional Chinese Classics and Reflections on the Necessity of the Interdisciplinary Approach in Translation Studies]." Jimei daxue xuebao 集美大學學報, no. 2 (2004):51-7.

Zhang Yin 張茵. “Mozi Shangxian zhong fanyi duibi de tantao《墨子.尚賢中》翻譯 對比的探討 [Discussing a Comparison of Translations of the Second Part of the Shangxian Chapter in Mozi]." Kejiao wenhui (Zhongxun kan) 科教文匯(中旬刊), Sep (2009): 251-65.

Zhi Yu 支羽 and Zhu Bo 朱波. “Chanshixue shijiao xia de yizhe zhutixing: Cong Wang Rongpei de Mozi yingyi tanqi 㘓釋學視角下的譯者主體性一從汪榕培的《墨子》 英譯談起 [Translator Subjectivity from the Perspective of Hermeneutics in Wang Rongpei's English Translation of the Mozi].” Xibei gongye daxue xuebao 西北工業大 學學報, no. 4 (2013): 84-7.

Zhu Jianping 朱健平et al. “Ai Qiao'en qi'e ban Mozi yingyi zhong shendu fanyi celüe yanjiu 艾乔恩企㧶鳥版《墨子》英譯中深度翻譯策略研究 [A Study of In-depth Translation Strategies in the English Translation of the Mozi by Ian Johnston Published by Penguin]." Waiyu jiaoxue 外語教學, no. 2 (2019): 99-103.

Zou Su 鄒素. “Mozi zongjiao guannian yingyi bianyi yanjiu:Yi Li Shaokun yingyiben wei li 《墨子》宗教觀念英譯變異研究—以李紹崑英譯本為例 [A Study on Variations of Religious Concepts in English Translations of the Mozi: Taking Cyrus Lee's Version as an Example]." Heilongjiang shengtai gongcheng zhiye xueyuan xuebao 黑龍江生 態工程職業學院學報, no. 2 (2017): 156-8. 